\title{
Phenolic Constituents, Anti-Inflammatory and Antidiabetic Activities of Cyperus laevigatus L.
}

\author{
Abdelsamed Ibrahim Elshamy 1,5*, Mohamed El-Shazly², Yomna Mahmoud Yassine ${ }^{1}$, Mona Anwar El-Bana ${ }^{3}$, Abdel- \\ Razik Farrag ${ }^{4}$, Mahmoud Ibrahim Nassar ${ }^{1}$, Abdel Nasser Singab², Masaaki Noji ${ }^{5}$, Akemi Umeyama ${ }^{5}$
}

\begin{abstract}
Abdelsamed Ibrahim Elshamy ${ }^{1,5 *}$, Mohamed El-

Shazly², Yomna Mahmoud Yassine ${ }^{1}$, Mona Anwar ElBana $^{3}$, Abdel-Razik Farrag ${ }^{4}$, Mahmoud Ibrahim Nassar $^{1}$, Abdel Nasser Singab², Masaaki Nojii , Akemi Umeyama $^{5}$

'Natural Compounds Chemistry Department, National Research Centre, 33 El Bohouth st., Dokki, Giza, 12622, EGYPT.

${ }^{2}$ Department of Pharmacognosy, Faculty of Pharmacy, Ain-Shams University, Cairo, EGYPT.

${ }^{3}$ Medical Biochemistry Department, National Research Centre, 33 El Bohouth st., Dokki, Giza, 12622, EGYPT.

${ }^{4}$ Department of Pathology, National Research Centre, 33 El Bohouth st., Dokki, Giza, P.O. Box 12622, EGYPT. ${ }^{5}$ Faculty of Pharmaceutical Sciences, Tokushima Bunri University, Yamashiro-cho, Tokushima 770-8514, JAPAN.

\section{Correspondence}

Dr. Abdelsamed I. Elshamy

Natural Compounds Chemistry, Department, National Research Centre, $33 \mathrm{El}$ Bohouth st., Dokki, Giza, 12622, EGYPT. \& Faculty of Pharmaceutical Sciences, Tokushima Bunri University, Yamashiro-cho Tokushima 770-8514, JAPAN.

Phone no: +20233371615

E-mail: elshamynrc@yahoo.com

History

- Submission Date: 02-06-2017;

- Review completed: 31-07-17

- Accepted Date: 17-08-2017

DOI : 10.5530/pj.2017.6.129

Article Available online

http://www.phcogj.com/v9/i6

Copyright

(C) 2017 Phcog.Net. This is an openaccess article distributed under the terms of the Creative Commons Attribution 4.0 International license.

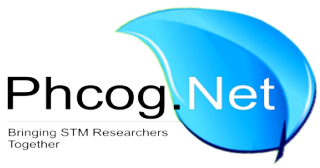

\begin{abstract}
Background: Cyperus species are well known traditional plants and used for several diseases around the world. Aim of the Study: Our study aimed to identification of the phenolic constituents in addition to evaluation of different extracts of Cyperus laevigatus $L$ as antioxidant, antiinflammatory and antidiabetic agents. Materials and Methods: The phenolic constituents were identified using spectroscopic techniques. The antioxidant activity was evaluated using in vitro DPPH assay. Total extract, methanol and EtOAc fractions were evaluated for their antiinflammatory activity using RAW 264.7 macrophages assay. Antidiabetic activity of the total extract was examined biochemically and histopathologically using streptozotocin-induced diabetic rats. Results: A new flavone, chrysoeriol 7-O- $\beta-\left(6^{\prime \prime \prime}-O\right.$-acetyl- $\beta$-D-glucopyranosyl)-( $\left.\rightarrow 44\right)$ glucopyranoside (1), along with seven knowns (2-8) were isolated from Cyperus laevigatus L. The structures of isolated compounds were established depending upon 1D, 2D-NMR and HR-ESI-MS. The $\mathrm{MeOH}$ and EtOAc fractions exhibited significant antioxidant activity while the isolated flavonoids exhibited from moderate to weak antioxidant activity. The total extract, $\mathrm{MeOH}$ and EtOAc fractions exhibited significant anti-inflammatory activity using LPS-stimulated RAW 264.7 macrophages model by decreasing of NO accumulation by $76-66 \%$ and $84-67 \%$, of the original accumulation values with increasing concentrations in comparison with the reference drug, dexamethasone. The total extract exhibited antidiabetic activity in streptozotocin-induced diabetic rats and this effect was manifested by decreasing serum levels of glucose, glucagon and NO. It also increased level of insulin and promoted paraoxonase activity. Conclusion: These results proved that this plant may be multiple sources for medicinal natural drugs especially for anti-inflammatory and antidiabetic.
\end{abstract}

Key words: Cyperus laevigatus, New Flavone, Antioxidant, Anti-Inflammatory, Antidiabetic.

\section{INTRODUCTION}

Cyperaceae is a largest family in the monocotyledons that includes more than 100 genera. Cyperus genus is the largest genus in this family that contains more than 600 species. $^{1}$ Cyperus species are widely used as weeds in traditional medicines. ${ }^{2}$ In 1983, Buolus reported that Cyperus species were traditionally used as an emollient to treat analgesic, diuretic, carminative and others. ${ }^{3}$ Pharmacological studies on Cyperus sp. indicated a myriad of biological effects such as antiinflammatory, hepatoprotective, gastroprotective, anti-malarial and anti-diabetic activities. ${ }^{4-7}$ Several secondary metabolites were reported from Cyperus sp. Including quinones, flavonoids, sesquiterpenes, steroids and essential oils.-8-10 Herein we report the phenolic constituents of the aerial parts of Cyperus laevigatus (Family: Cyperaceae) as well as the pharmacological effects of the different extracts and isolated compounds.

\section{MATERIALS AND METHODS}

\section{General Experimental procedures}

Optical rotation was measured using JASCO P1020 polarimeter (JASCO International Co. Ltd., Tokyo, Japan). NMR spectra were recorded on JEOL AL-400 NMR spectrometer (JEOL Inc., Tokyo, Japan). HR-ESI-MS were recorded by a Shimadzu LC-MS-IT-TOF-MS spectrometer (Shimadzu Inc., Kyoto, Japan). An OMM 7070E Shimadzu visible recording model UV 200 and 240 spectrophotometers (Shimadzu Inc., Kyoto, Japan) were used for UV spectra.

\section{Plant material}

Aerial parts of Cyperus laevigatus L., were collected from Baltim, Kafr Elsheikh, Egypt, in April 2013 and kindly identified by Asoc. Prof. Ahmed M. Abdel Gawad. A voucher specimen (PHG-P-CL179) was deposited in Ain Shams University herbarium, Cairo, Egypt.
Cite this article: Elshamy Al, El-Shazly M, Yassine YM, El-Bana MA, Farrag AH, Nassar MI, Singab ANB, Noji M, Umeyama A. Phenolic Constituents, Anti-Inflammatory and Antidiabetic Activities of Cyperus laevigatus L.. Pharmacog J. 2017;9(6):828-33. 


\section{Extraction and isolation}

Air-dried powder aerial parts of C. laevigatus $(2.0 \mathrm{~kg})$ were extracted by $70 \% \mathrm{MeOH}$, filtered, and dried under vacuum to give dark black gum (85.0 gm). The dry extract was successively fractionated using $n$-hexane (12.0), $\mathrm{CH}_{2} \mathrm{Cl}_{2}$ (10.0), EtOAc (11.0) and $\mathrm{MeOH}$ (52.0), respectively. The $\mathrm{MeOH}$ fraction was subjected to polyamide $\mathrm{CC}$ and eluted with $\mathrm{H}_{2} \mathrm{O}$ : EtOH in gradient afforded 8 major fractions (CL-1:CL-8). Fraction CL-3 ( $160.0 \mathrm{mg} ; 25 \% \mathrm{MeOH}$ ) was subjected to preparative paper chromatography that afforded two subfractions CL-3 (A, $112 \mathrm{mg}$; $R f: 0.4 \mathrm{AcOH}$ ) and (B; $43 \mathrm{mg} ; R f: 0.65 \mathrm{AcOH}$ ). Subfractions CL-3-B was eluted on Sephadex LH-20 by $40 \% \mathrm{MeOH}$ afforded compound 1 (8.3 mg). The other seven flavonoids (2-8) were purified using different chromatographic techniques such as preparative paper and Sephadex LH-20 column. Complete acid hydrolysis followed by PC investigation was preceded. ${ }^{11}$

\section{Spectroscopic data of new flavonoid (1)}

Yellow amorphous solid (8 mg), $\left\{[\alpha]_{\mathrm{D}}^{25}-16^{\circ}(\mathrm{c} 0.01, \mathrm{MeOH})\right\}, \mathrm{UV} \lambda_{\max } \mathrm{nm}$ (MeOH): 208, 266, 347; NaOAc: 213, 260, 348, 368; + Boric acid: 215, 258, 348; $\mathrm{AlCl}_{3}: 211,279,306.6,355.4$; + HCl: 216.2, 277.2 , 300.8, 347.4; $\mathrm{H}_{3} \mathrm{BO}_{3}: 209.2,269.6,336.6$; +NaOAc: $221.8,270.8,334.8$. HR-ESI-MS $m / z: 689.6365[\mathrm{M}+\mathrm{Na}]^{+}$, ESI-MS $m / z[\mathrm{M}-\mathrm{H}]:$ : 666.1. ${ }^{1} \mathrm{H}-(400 \mathrm{MHz})$; ${ }^{13} \mathrm{C}-(100 \mathrm{MHz}$; DMSO-d6) NMR (see Table 1).

\section{Antioxidant activity of $C$. laevigatus extracts}

The antioxidant activity of the different extracts of $C$. laevigatus aerial parts along with the isolated flavonoids 1-8 were evaluated in terms of DPPH radical-scavenging ability, as described before ${ }^{12}$ in a comparising with a reference drug, ascorbic acid.

\section{Anti-inflammatory activity of different extracts of C. laevigatus}

The anti-inflammatory of total extract, $\mathrm{MeOH}$ and EtOAc fractions was evaluated at different concentrations $(12.5,25,50$ and $100 \mu \mathrm{g} / \mathrm{ml})$ using LPS-stimulated RAW264.7 macrophages model with a reference drug, dexamethasone as described previously. ${ }^{13}$

\section{Cell culture}

Raw murine macrophages (RAW 264.7) were purchased from the American Type Culture collections and cultured in RPMI-1640 supplemented with $10 \%$ fetal bovine serum (FBS), $2 \mathrm{mM} \mathrm{L}$-glutamine, containing $100 \mathrm{U} / \mathrm{mL}$ penicillin G sodium, $100 \mathrm{U} / \mathrm{mL}$ streptomycin sulphate, and $250 \mathrm{ng} / \mathrm{ml}$ amphotericin B. Cells were maintained in humidified air containing 5\% $\mathrm{CO}_{2}$ at $37^{\circ} \mathrm{C}$ (Cambrex BioScience, Copenhagen, Denmark).

\section{MTT cell viability assay}

The mitochondrial-dependent reduction of MTT to formazan was used to measure cell respiration as an indicator of cell viability. ${ }^{13}$ Cells $(0.5 \times$ $10^{5}$ cells/ well) in serum-free media were plated in a flat bottom 96-well microplate, and treated with $20 \mu \mathrm{L}$ of different concentrations of the tested samples for $24 \mathrm{~h}$ at $37^{\circ} \mathrm{C}$, in a humidified $5 \% \mathrm{CO}_{2}$ atmosphere. After incubation, the media were removed and $40 \mu \mathrm{L}$ MTT solution / well was added and incubated for an additional $4 \mathrm{~h}$. MTT crystals were solubilized by adding $180 \mu \mathrm{L}$ of acidified isopropanol/well and the plate was shacked at room temperature, followed by photometric determination of the absorbance at $570 \mathrm{~nm}$ using 96 wells microplate ELISA reader.

\section{Inhibition of nitric oxide (NO) production}

Raw murine macrophages (RAW 264.7) were seeded in 96-well plates at $0.5 \times 10^{5}$ cells / well for $2 \mathrm{~h}$ in RPMI without phenol red. The cells were stimulated with LPS with final concentrations of $10 \mu \mathrm{g} / \mathrm{mL}$. The stimulated cells after 2 extra h were treated with serial concentrations of the tested samples, dexamethasone $(50 \mu \mathrm{g} / \mathrm{mL})$ or left with the LPS alone. Untreated cells were used as a negative control. ${ }^{13}$

Nitrite accumulation was used as an indicator of $\mathrm{NO}$ production using a microplate assay based on the Griess reaction. In each well of flat bottom 96 well-microplates, $40 \mu \mathrm{L}$ of freshly prepared Griess reagent was mixed with $40 \mu \mathrm{L}$ cell supernatant or different concentrations of sodium nitrite ranging from $0-100 \mu \mathrm{mol} / \mathrm{L}$. The plate was incubated for $10 \mathrm{~min}$ in the dark and the absorbance of the mixture at $540 \mathrm{~nm}$ was determined using the microplate ELISA reader. The amount of nitrite in the media was calculated from NO standard curve.

\section{Antidiabetic activity of total alcoholic extract of C. laevigatus \\ Chemicals and animals}

Streptozotocin (STZ) was purchased from Sigma Chemical Co. St. Louis, MO, USA. The study was conducted on 60 adult albino rats (200-210 g) (National Research Centre (NRC), Dokki, Giza, Egypt). Rats were performed in accordance with the Ethics Committee of the NRC. Rats were divided into 4 groups ( 15 rats in each) as follow: control group, rats received intragastric C. laevigatus $\mathrm{MeOH}$ fraction $(50 \mathrm{mg} / \mathrm{kg}$ b.w. day) dissolved in distilled water, Diabetic group, diabetes were induced by single subcutaneous injection of streptozotocin $(50 \mathrm{mg} / \mathrm{kg}$ b.w.) The animals were considered diabetic if fasting glucose level was $200 \mathrm{mg} / \mathrm{dL}$ after 48 hours of the injection, treated group, diabetic rats received intragastric C. laevigatus total extract $\left(50 \mathrm{mg} / \mathrm{kg}\right.$ b. w. day). ${ }^{14}$

\section{Biochemical Analysis}

Serum glucose was performed according to the method of Passing, $1983 .{ }^{15}$ Serum glucagon and insulin were performed according to previous reported methods. ${ }^{15,16} \mathrm{NO}$ was determined according to the reported method ${ }^{17}$ where nitrite, stable end product of nitric oxide radical, is mostly used as indicator for the production of NO. The activity of paraoxonase was measured spectrophotometrically in supernatants using phenyl acetate as the substrate. In this assay, aryl esterase/paraoxonase catalyzes the cleavage of phenyl acetate, resulting in phenol formation. The rate of phenol formation is measured by monitoring the increase in absorbance at $270 \mathrm{~nm}$ at $25^{\circ} \mathrm{C}$. Absorbance at $270 \mathrm{~nm}$ was taken every $15 \mathrm{~s}$ for $120 \mathrm{~s}$ using UV Spectrophotometer. ${ }^{18}$

\section{Histopathological evaluation}

The pancreatic tissues were dissected out immediately, fixed in 10\% normal formalin dehydrated in series of alcohol and then to xylene each for $1 \mathrm{~h}$ followed by embedding in wax at $60^{\circ} \mathrm{C}$. Paraffin blocks of the tissues were sectioned to $5 \mu \mathrm{m}$ thickness. The sections were then stained with hematoxylin and eosin for histopathological evaluation. ${ }^{19}$

\section{Statistical analysis}

All data were expressed as mean \pm standard error. Data were analyzed using one-way ANOVA using SPSS (Version 16). Duncan's new multiplerange test was used to assess differences between means. A significant difference was considered at the level of $\mathrm{P}<0.05$.

\section{RESULTS AND DISCUSSION}

A new acylated flavone diglucoside namely, chrysoeriol 7-O- $\beta$ $\left(6^{\prime \prime \prime}\right.$-O-acetyl- $\beta$-D-glucopyranosyl)- $(1 \rightarrow 4)$ glucopyranoside (1) and seven knowns, apigenin (2), apigenin 7-O- $\beta$-glucopyranoside (3), luteolin (4), luteolin 7-O- $\beta$-glucopyranoside (5), chrysoeriol (6), chrysoeriol $7-O$ - $\beta$-glucopyranoside (7), and tricin $(8)^{20,21}$ were isolated for the first time from the aerial parts of C. laevigatus (Figure 1A). The structures 
<smiles>[R20]c1cc(O)c2c(=O)cc(-c3cc([R])c([R])c([R])c3)oc2c1</smiles>

\begin{tabular}{ccccc}
\hline No & $\mathrm{R}$ & $\mathrm{R}_{1}$ & $\mathrm{R}_{2}$ & $\mathrm{R}_{3}$ \\
\hline 1 & $\mathrm{O}$ & $\mathrm{OCH}$ & $\mathrm{OH}$ & $\mathrm{H}$ \\
2 & $\mathrm{H}$ & $\mathrm{OH}$ & $\mathrm{H}$ \\
3 & $\beta-g l u$ & $\mathrm{H}$ & $\mathrm{OH}$ & $\mathrm{H}$ \\
4 & $\mathrm{H}$ & $\mathrm{OH}$ & $\mathrm{OH}$ & $\mathrm{H}$ \\
5 & $\beta-g l u$ & $\mathrm{OH}$ & $\mathrm{OH}$ & $\mathrm{H}$ \\
6 & $\mathrm{H}$ & $\mathrm{OCH}_{3}$ & $\mathrm{OH}$ & $\mathrm{H}$ \\
7 & $\beta-g l u$ & $\mathrm{OCH}_{3}$ & $\mathrm{OH}$ & $\mathrm{H}$ \\
8 & $\mathrm{H}$ & $\mathrm{OCH}_{3}$ & $\mathrm{H}$ & $\mathrm{OCH}_{3}$ \\
\hline
\end{tabular}

Figure 1A: Isolated flavonoids from C. laevigatus.

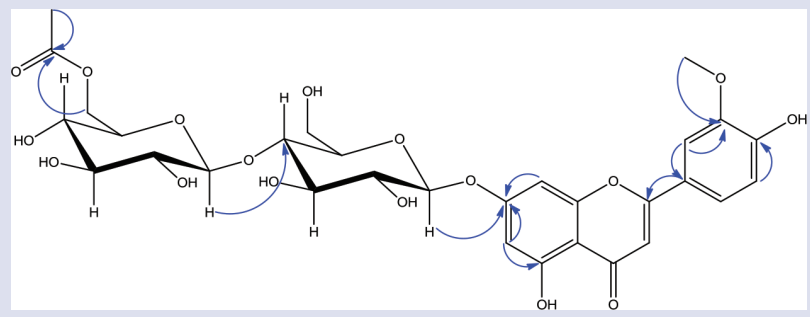

Figure 1B: Significant HMBC $(\rightarrow)$ correlations of the new flavonoid(1)

of isolated compounds were established using spectroscopic methods, including UV, 1D, 2D-NMR and HR-ESI-MS.

UV spectroscopic data of compound (1) indicated a flavone with free 5 and 4'-hydroxyl groups. ${ }^{11}$ HR-ESI-MS spectrum showed a molecular ion peak $[\mathrm{M}+\mathrm{Na}]^{+}$at $\mathrm{m} / z 689.6365$, corresponding to the molecular formula of $\mathrm{C}_{30} \mathrm{H}_{34} \mathrm{O}_{17}$. The ${ }^{1} \mathrm{H}$-NMR spectral data (Table 1) showed a downfield shift of H-6 at $\delta_{\mathrm{H}} 6.41(\mathrm{~d}, J=2.0), \mathrm{H}-8$ at $6.77(\mathrm{~d}, J=2.0 \mathrm{~Hz})$ suggested the presence of C-7-O-substitution. A characteristic signal of methoxy group at $\delta_{\mathrm{H}} 3.91 \mathrm{~s}$ was detected. Additionally, the spectrum showed two anomeric protons at $\delta_{\mathrm{H}} 5.11(\mathrm{~d}, J=7.2)$ and at $\delta_{\mathrm{H}} 5.08(\mathrm{~d}, J=7.2)$. The signals appeared at $\delta_{\mathrm{H}} 3.16-4.11$ were attributed to the protons of the remaining sugar. A characteristic proton signal of one methyl for acetyl group was observed at $\delta_{\mathrm{H}} 2.15 \mathrm{~s} .{ }^{13} \mathrm{C}-\mathrm{NMR}$ spectrum showed 30 carbon resonances (Table 1), two of which were carbonyls which appeared at $\delta_{\mathrm{C}} 182.3$ for C- 4 and at $\delta_{\mathrm{C}} 172.3$ for characteristic for an acetoxy group. Dept-145 experiment suggested the presence of two methylene, sixteen methine signals, one metyl of methoxy group (at $\delta_{C} 56.1$ ); ome methyl
Table 1: ${ }^{1} \mathrm{H}-(400 \mathrm{MHz})$ and ${ }^{13} \mathrm{C}-\mathrm{NMR}(100 \mathrm{MHz})$ of compound 1 (DMSOd6).

\begin{tabular}{|c|c|c|}
\hline Position & ${ }^{1} \mathrm{H}-\mathrm{NMR}$ & ${ }^{13} \mathrm{C}-\mathrm{NMR}$ \\
\hline \multicolumn{3}{|l|}{ - Aglycon } \\
\hline 2 & --- & 164.9 \\
\hline 3 & $6.71 \mathrm{~s}$ & 104.8 \\
\hline 4 & --- & 182.3 \\
\hline 5 & --- & 161.5 \\
\hline 6 & $6.41 \mathrm{~d}(J=2.0 \mathrm{~Hz})$ & 99.9 \\
\hline 7 & ------- & 163.4 \\
\hline 8 & $6.77 \mathrm{~d}(J=2.0 \mathrm{~Hz})$ & 94.9 \\
\hline 9 & --- & 157.3 \\
\hline 10 & --- & 105.6 \\
\hline $1^{\prime}$ & --- & 121.5 \\
\hline $2^{\prime}$ & $7.34 \mathrm{~s}$ & 113.8 \\
\hline 3' & --- & 148.6 \\
\hline $4^{\prime}$ & --- & 146.2 \\
\hline $5^{\prime}$ & $6.9 \mathrm{~d}(J=8.0 \mathrm{~Hz})$ & 116.4 \\
\hline $6^{\prime}$ & $7.42 \mathrm{~d}(J=8.0 \mathrm{~Hz})$ & 119.5 \\
\hline $\mathrm{OCH}_{3}$ & $3.91 \mathrm{~s}$ & 56.1 \\
\hline \multicolumn{3}{|l|}{ - $\quad$ 7-O-Glc } \\
\hline $1 "$ & $5.11 \mathrm{~d}(J=7.2 \mathrm{~Hz})$ & 99.8 \\
\hline $2 "$ & & 73.2 \\
\hline 3" & $\begin{array}{l}n \\
\stackrel{1}{0}\end{array}$ & 73.5 \\
\hline $4 "$ & 1 & 79.5 \\
\hline $5 "$ & $\ddot{n}$ & 74.2 \\
\hline $6 ”$ & & 62.3 \\
\hline \multicolumn{3}{|l|}{ - $\quad{ }^{4}$ Glc-O- Glc } \\
\hline $1 "$ & $5.08 \mathrm{~d}(J=7.2 \mathrm{~Hz})$ & 100.0 \\
\hline $2 "$ & & 75.3 \\
\hline $3 " \prime$ & $\exists$ & 76.6 \\
\hline 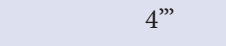 & $\begin{array}{l}1 \\
6\end{array}$ & 72.1 \\
\hline $5 "$ & $\vec{m}$ & 73.5 \\
\hline $6 "$ & & 63.3 \\
\hline $\mathrm{OCH}_{3}$ & $3.91 \mathrm{~s}$ & 56.7 \\
\hline \multicolumn{3}{|l|}{ - $\quad 6^{\prime \prime}$ Acetate } \\
\hline $\mathrm{CO}$ & --- & 172.3 \\
\hline $\mathrm{COOCH}_{3}$ & $2.15 \mathrm{br} \mathrm{s}$ & 21.1 \\
\hline
\end{tabular}

${ }^{*}$ All assignments are based on 1D and 2D measurements (HMBC, HSQC, COSY).

for acetoxy group (at $\delta_{\mathrm{C}} 21.1$ ) and ten quaternary carbon signals. The C-7-O-sabstitution was suggested by the downfield shift carbon signal of C-7 at $\delta_{\mathrm{C}}$ 163.4. Ten carbon signals for two glucosyl moieties were showed at $\delta_{C} 73.2$ (C-2"), 73.5 (C-3"), 79.5 (C-4"), 74.2 (C-5"), 62.3 (C-6”), 75.3 (C-2"'), 76.6 (C-3"”), 72.1 (C-4"”), 73.5 (C-5"'), 63.3 (C-6"'), two anomeric carbons at $\delta_{\mathrm{C}} 99.8(\mathrm{C}-1$ ") $), \delta_{\mathrm{C}} 100.0$ (C-1"'). The assignment of the protonated carbons was established by HSQC experiment. The 7-O-glucosidic linkage was confirmed by HMBC correlation of the anomeric proton at $\delta_{\mathrm{H}} 5.11\left(\mathrm{~d}, J=7.20, \mathrm{H}-1\right.$ ”) and C-7 at $163.4\left(\mathcal{\beta}^{3}\right)$. The very clear downfield shieft of C-4" at $\delta_{\mathrm{C}} 79.5$ in addition to the HMBC correlation of the anomeric proton at $\delta_{\mathrm{H}} 5.08\left(\mathrm{~d}, J=7.20,1^{\prime \prime}\right)$ with the C-4" $\left(\mathcal{J}^{3}\right)$ deduced the $4 " \rightarrow 1$ "' diglucoside linkage ${ }^{22}$. Also the downfield shieft of the C-6"' by approximately 1 ppm at $\delta_{C} 63.3$ suggested the acetylated C-6"' that supported by HMBC correlation of $\mathrm{H}-6$ "' at $\delta_{\mathrm{H}} 3.16$ 
Table 2: Antioxidant activity of C. laevigatus extracts and isolated flavonoids (1-8).

\begin{tabular}{cc}
\hline Tested sample & DPPH assay $\mathrm{IC}_{50}(\mu \mathrm{g} / \mathrm{ml})$ \\
\hline n-hexane fraction & $76.98 \pm 2.69$ \\
EtOAc fraction & $57.58 \pm 1.93$ \\
MeOH fraction & $24.28 \pm 0.67$ \\
Compd 1 & $65.93 \pm 1.57$ \\
Compd 2 & $28.78 \pm 1.21$ \\
Compd 3 & $34.12 \pm 0.98$ \\
Compd 4 & $26.54 \pm 1.03$ \\
Compd 5 & $31.19 \pm 1.14$ \\
Compd 6 & $33.76 \pm 0.87$ \\
Compd 7 & $52.62 \pm 0.65$ \\
Compd 8 & $58.44 \pm 1.74$ \\
Ascorbic acid & $1.85 \pm 0.12$ \\
\hline
\end{tabular}

m with the acetyl carbonyl group at $\delta_{\mathrm{C}} 172.3\left(\mathcal{\beta}^{3}\right)$. Moreover, a correlation between the methyl proton signal at $\delta_{\mathrm{H}} 2.15 \mathrm{~s}$ and the carbonyl group at $\delta_{\mathrm{C}} 172.3\left(J^{2}\right)$ was observed. Also the HMBC correlation between the methyl proton at $\delta_{\mathrm{H}} 3.91 \mathrm{~s}$ and $\mathrm{C}-3^{\prime}$ at $\delta_{\mathrm{C}} 148.6\left(J^{3}\right)$ indicated methoxylation of $\mathrm{C}-3$ ' (Figure $1 \mathrm{~B}$ ). The $\beta$ orientation of the glucosidic linkage was confirmed was by the large coupling constant of the anomeric proton $(7.2 \mathrm{ppm}){ }^{22,23}$ The structure of this compound was confirmed by mass fragments; at $\mathrm{m} / z 367.1056$ characteristic to 6 "' $O$-acetyl- $\beta$ $D$-diglucopyranoside; at $\mathrm{m} / z 301.1413$ characteristic to chrysoeriol and at $\mathrm{m} / \mathrm{z} 461.2$ in the negative mode ESI-MS characteristic to chrysoeriol-7-O-glucoside. The acid hydrolysis of $\mathbf{1}$ afforded an aglycone and a sugar moiety, which was composed of chrysoeriol and glucose. From the above mentioned data, the structure of $\mathbf{1}$ was characterized as chrysoeriol 7-O- $\beta$-(6"'-O-acetyl- $\beta$-D-glucopyranosyl)-( $1 \rightarrow 4)$ glucopyranoside (1)

\section{Antioxidant activity}

The total extract and $\mathrm{MeOH}$ fractions showed moderate DPPH radical scavenging activity with $\mathrm{IC}_{50} 23.39 \pm 0.72$ and $24.28 \pm 0.56$, respectively but EtOAc, and $n$-hexane showed weak activity with $\mathrm{IC}_{50} 57.89 \pm 0.71$, and $76.98 \pm 0.73$, respectively. Also the isolated flavonoids exhibited from moderate to weak antioxidant activity by the order of compound 4 $>\mathbf{2}>\mathbf{5}>\mathbf{6}>\mathbf{3}>\mathbf{7}>\mathbf{8}>\mathbf{1}$ (Table 2). The moderate antioxidant activity of both the total extract and $\mathrm{MeOH}$ fraction was attributed to the high flavonoid content. It was reported that flavonoids possess antioxidant activity especially luteolin derivatives and methoxylated flavonoids. ${ }^{24}$ The DPPH reaction mechanism with the compounds that exhibited activity depending upon the free $\mathrm{OH}$ groups in $\mathrm{B}$-ring, so the flavons exhibited more activity that the flavons 7 -O-glycosides. ${ }^{25}$

\section{Anti-inflammatory activity}

Cytotoxicity results confirmed that the tested extracts are safe on RAW264.7 macrophages with different concentrations (12.5, 25, 50 and $100 \mu \mathrm{g} / \mathrm{ml})$. The total extract $(12.5,25,50$, and $100 \mu \mathrm{g} / \mathrm{ml})$ and $\mathrm{MeOH}$ fraction $(12.5,25$, and $50 \mu \mathrm{g} / \mathrm{ml})$ decreased NO\% accumulation as the concentration increased reaching $76-66 \%$ and $84-67 \%$, respectively. Also, the EtOAc fraction $(12.5,25$, and $50 \mathrm{mg}$ ) decreased the NO\% accumulation with concentration increased with values ranging from $77-66 \%$. The results of the anti-inflammatory assay suggested that the total, $\mathrm{MeOH}$ and EtOAc extracts exhibited potent activity at different concentrations and the results were comparable with the reference drug,

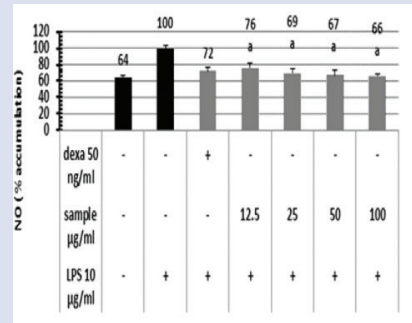

A

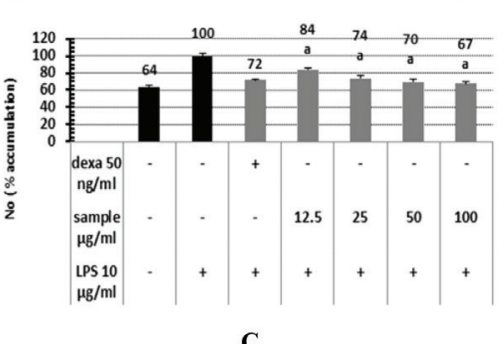

Figure 2: NO\% accumulation in response to; $\mathrm{B}$ ) total extract; C) $\mathrm{MeOH}$ fraction and D) EtOAC fraction of $C$. laevigatus. The results were compared with the results of LPS stimulated cells, non-treated cells and dexamethasone $(50 \mathrm{\mu g} / \mathrm{ml})$ treated cells. ${ }^{a} \mathrm{P} \leq 0.005$, ${ }^{\mathrm{b}} \mathrm{P} \leq 0.0005$ compared to LPS stimulated cells.

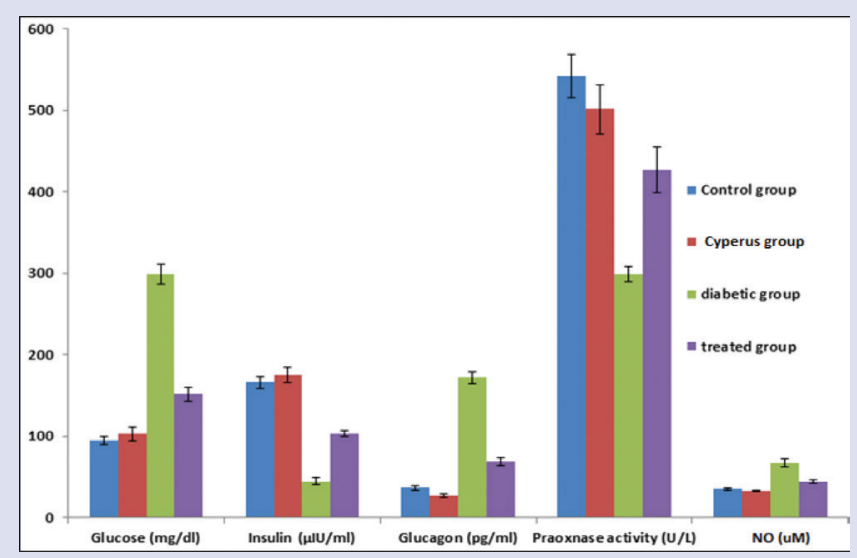

Figure 3: Mean serum glucose, glucagon and NO levels were significantly high and serum insulin and serum praoxnase activity level were significantly low in diabetic group compared to normal group. Mean serum glucose, glucagon and NO levels were significantly low and serum insulin and serum praoxnase activity level were significantly high in treated group compared to diabetic group. 

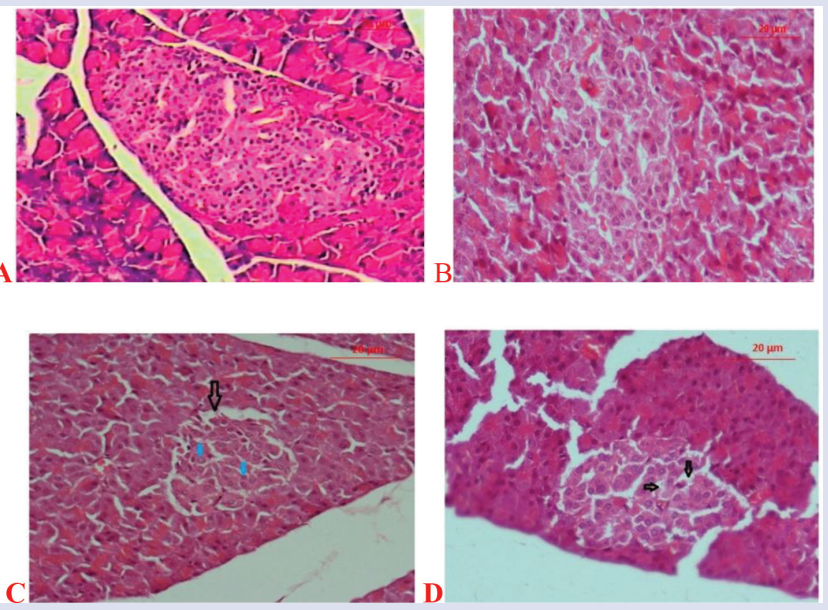

Figure 4: Section of pancreas of A) control group shows the normal structure of exocrine (dense-staining acinar cells) and endocrine pancreas (light-staining islet of Langerhans), B) rat treated with C. laevigatus extract ( $50 \mathrm{mg} / \mathrm{kg}$ b.w./day) shows the normal structure of exocrine and endocrine pancreas, $\mathrm{C}$ ): diabetic rat shows decrease in pancreatic islet size, atrophy and vacuolation, and connective tissue invasion in the parenchyma of pancreas islet (black arrow) is shown. A reduction in the pancreatic b-cell (blue arrow) numbers compared to the control group, D): diabetic rat received intragastric C. laevigatus extract ( $50 \mathrm{mg} / \mathrm{kg}$ b.w./day) shows normal structure of the pancreas. Few degenerative cells (black arrow) are seen in the islet ( $\mathrm{H} \& \mathrm{E}$ stain, Scale Bar: $20 \mu \mathrm{m}$ ).

Biochemical markers in the present work exhibited that the diabetic group treated with $C$. laevigatus extract showed a decrease in the glucose, glucagon, and NO serum levels and promote serum insulin and paraoxonase levels. Zhang et al. $2010^{27}$ reported that flavonoids exhibited antidiabetic activity by decreasing fasting blood glucose (FBG) and glucagon serum levels while increasing insulin serum levels (Figure 3). Histological examination of the pancreas of the control and extract treated rats indicated normal architecture (Figure 4-A; B). The islets of Langerhans found in the pancreatic tissue were round in shape with normal cell lining. On the other hand, the acini were arranged in a well-organized manner. The interlobular ducts were surrounded with the supporting tissue. These results were consistent with Jarral et al. $2013^{28}$ that found that beta-cells comprise the major of islets' cells of rat's pancreas.

In the diabetic rats, the pancreas showed a decrease in the pancreatic islet size, atrophy, vacuolation, and connective tissue invasion in the parenchyma of the pancreas islets. The sections revealed a reduced pancreatic $\beta$-cell numbers compared to the control group (Figure 4-C). STZinduced diabetes may be due to the selective destroying of pancreatic $\beta$-cells, which is responsible for the insulin production from endocrine cells. ${ }^{29}$ The pancreas of the diabetic rats treated with C. laevigatus extract showed dramatic suppression of all abnormal histological changes as compared to the diabetic group (Figure 4-D).

The pancreas of the diabetic rats treated with C. laevigatus extract showed dramatic suppression of all abnormal histological changes. Regarding the mechanism by which $C$. laevigatus can improve $\beta$-cells, researchers found that flavonoids, flavonoid glycosides and phenolic acids exhibited a strong contribution as antioxidant agents that can regenerate the changes in the morphology of $\beta$-cells. ${ }^{24-30-31}$

\section{CONCLUSION}

A new flavonoid, chrysoeriol 7-O- $\beta$ - $\left(6^{\prime \prime \prime}-\mathrm{O}\right.$-acetyl- $\beta$-Dglucopyranosyl)-( $1 \rightarrow 4$ ) glucopyranoside $(1)$, and seven knowns (2-8) were isolated and identified from aerial parts of $C$. laevigatus alcoholic extract. The different extracts and isolated compounds exhibited from moderate to low antioxidant activity. The total acoholic extract, $\mathrm{MeOH}$ and EtOAC fractions exhibited significant anti-inflammatory activity using by decreasing of NO accumulation in comparison with dexamethasone as a reference drug using LPS-stimulated RAW 264.7 macrophages model. The $\mathrm{MeOH}$ fraction exhibited antidiabetic activity by decreasing levels of glucose, glucagon and NO along with increasing level of insulin and promoted paraoxonase activity in streptozotocin-induced diabetic rats.

\section{ACKNOWLEDGEMENT}

This work was supported by the research project of the National Research Centre (Project ID: 10010303) and the Faculty of Pharmaceutical Science; Tokushima Bunri University.

\section{CONFLICT OF INTEREST}

The authors declare no conflict of interests.

\section{ABBREVIATION USED}

DPPH: 2,2-diphenyl-1-picrylhydrazyl; RAW 264.7: Mouse RAW-264.7 Cell lines; 1D, 2D-NMR: one and two dimensional nuclear magnetic resonance; NO: Nitric Oxide; PC: Paper Chromatography; MTT: (3-(4,5-Dimethylthiazol-2-yl)-2,5-Diphenyltetrazolium Bromide.

\section{REFERENCES}

1. Simpson DA, Inglis CA. Cyperaceae of economic, ethnobotanical and horticultural importance. Kew Bull. 2001;56:257-360.

2. Vilhena KS, Guilhon SM, Zoghbi M, Santos L., Filho A. Chemical investigation of Cyperus distans L. and inhibitory activity of scabequinone in seed germination and seedling growth bioassays. Nat Prod Res. 2014;28(23):2128-33

3. Buolus L. Medicinal Plants of North Africa. Reference Publications Inc., 1983. Egypt.

4. Kumar SVS, Mishra H. Hepatoprotective activity of rhizomes of Cyperus rotundus linn against carbon tetrachloride-induced hepatotoxicity. Ind J of pharm Sci. 2005;67(1):84-8.

5. Kumari CS, Govindasamy S, Sukumar E. Lipid lowering activity of Eclipta prostrata in experimental hyperlipidemia. Journal of Ethnopharmacology. 2006;105(3):332-5.

6. Thebtaranonth C, Thebtaranonth Y, Wanauppathamkul S, Yuthavong Y. Antimalarial sesquiterpenes from tubers of Cyperus rotundus: structure of 10,12-Peroxycalamenene, a sesquiterpene endoperoxide. Phytochem. 1995; 40(1):125-8.

7. Raut NA, Gaikwad NJ. Antidiabetic activity of hydro-ethanolic extract of Cyperus rotundus in alloxan induced diabetes in rats. Fitoterapia. 2006;77(7-8):585-88.

8. Abdel-Razik AF, Nassar MI, El-Khrisy ED, Dawidar AA, Mabry TJ. New prenylflavans from Cyperus conglomeratus. Fitoterapia. 2005 Dec 31;76(7):762-4.

9. Nassar MI, Yassine YM, Elshamy Al, El-Beih A, El-Shazly M, Singab A. Essential oil and antimicrobial activity of aerial parts of Cyperus leavigatus L. (Family: Cyperaceae). J of Ess Oil Bearing Plants 2015;18(2):416-422.

10. Xu Y, Zhang HW, Yu CY, Lu Y, Chang Y, Zou ZM. Norcyperone, a novel skeleton norsesquiterpene from Cyperus rotundus L. Molecules 2008;13(10):2474-81.

11. Mabry T, Markham K, Thomas M. The Systematic Identification of Flavonoids. Publ, 1970; New York.

12. Hyun TK, Kim HC, Kim JS. Antioxidant and antidiabetic activity of Thymus quinquecostatus Celak. Industrial Crops and Products. 2014;52:611-6.

13. Hyun TK, Ko YJ, Kim EH, Chung IM, Kim JS. Anti-inflammatory activity and phenolic composition of Dendropanax morbifera leaf extracts. Industrial Crops and Products. 2015;74:263-70.

14. Simeonova R, Vitcheva V, Krasteva I, Zdraveva P, Konstantinov S, lonkova I. Antidiabetic and antioxidant effects of saponarin from Gypsophila trichotoma on streptozotocin-induced diabetic normotensive and hypertensive rats. Phytomedicine. 2016;23(5):483-90.

15. Passing $\mathrm{H}$, and Bablok $\mathrm{PH}$. A new biometrical procedure for testing the equality of measurements from two different analytical methods. Application of linear regression procedures for method comparison studies in clinical chemistry, 
Part I. J Clin Chem Clin Biochem. 1983;21(11):709-20.

16. Judzewitsch RG, Pfeifer MA, Best JD, Beard JC, Halter JB, Porte D Jr. Chronic chlorpropamide therapy of noninsulin-dependent diabetes augments basal and stimulated insulin secretion by increasing islet sensitivity to glucose. J Clin Endocrinol Metab. 1982;55(2):321-8

17. Moshage $H$, Kok B, Huizenga JR, Jansen PL. Nitrite and nitrate determinations in plasma: a critical evaluation. Clin Chem. 1995;41(6 Pt 1):892-6.

18. Hussein J, Abdel L, El-Bana M, Medhat D, Morsy S, El-Toukhy S, et al. New approach in treatment of brain injury: Neurotrophic effects of Apigenin. J of Chem and Pharmac Res. 2015:17(5):996-1004.

19. Drury RAB, Wallington EA. Preparation and fixation of tissues. In: Drury RAB, Wallington EA, editors.Carleton's Histological Technique. 5. Oxford: Oxford University Press. 1980;41-54.

20. Deng Y, Song A and Wang H. Chemical Components of Seriphidium Santolium Poljak. J Chin Chem Soc. 2004;51(3):629-36.

21. Huang W, Wu S-B, Wang Y, GuoZ-Y, Kennelly E, Long C. Chemical constituents from Striga asiatica and its chemotaxonomic study. Biochem System and Ecol. 2013;48:100-6

22. Hasan A, Ahmed I, Jay M, Voirin B. Flavonoid glycosides and an anthraquinone from Rumex chalepensis. Phytochem. 1995;39(5):1211-13.

23. Delazar A, Celik S, Gokturk RS, Unal O, Nahar L, Sarker SD. Two acylated flavonoid glycosides from Stachys bombycina, and their free radical scavenging activity. Pharmazie 2005;60(11):878-80

24. Akimanya A, Midiwo J, Matasyoh J, Okanga F, Masila V, Walker L, et al. Two polymethoxylated flavonoids with antioxidant activities and a rearranged clerodane diterpenoid from the leaf exudates of Microglossa pyrifolia. Phytochem Lett. 2015;11:183-7.

25. Hammad H, Albu C, Matar S, Litescu S-C, Jaber $H$, Abualraghib A, et al. Biological activities of the hydro-alchoholic and aqueous extracts of Achillea biebersteinii Afan. (Asteraceae) grown in Jordan. Afr. J. Pharm. Pharmacol. 2013;7(25):1686-94

26. Choi J, Nurul M, Yousof M, Kim E, Kim Y, Jung H. Effects of C-glycosylation on anti-diabetic, anti-Alzheimer's disease and anti-inflammatory potential of apigenin. Food Chem Toxic. 2014;64:27-33.

27. Zhang L, Yang J, Chen X, Zan K, Wen X, Chen H, Wang Q, Lai M. Antidiabetic and antioxidant effects of extracts from Potentilla discolor Bunge on diabetic rats induced by high fat diet and streptozotocin. J Ethnopharm. 2010;132(2):518-24.

28. Jarral S., Tahir M., Lone K. Postnatal Histogenesis of Islets of Langerhans in Rat Pakistan J Zool. 2013;45(2):323-9.

29. Kavalali G, Tuncel H, Goksel S, Hatemi H. Hypoglycemic activity of Urtica pilulifera in streptozotocin-diabetic rats. J Ethnopharm. 2003;84:241-5.

30. Das S, Barman S. Antidiabetic and antihyperlipidemic effects of ethanolic extract of leaves of Punica granatum in alloxan-induced non-insulin-dependent diabetes mellitus albino rats. Indian J Pharmacol. 2012;44(2):219-24.

31. Verma VK, Sarwa KK, Zaman KMD. Antihyperglycemic activity of swertia chirayita and andrographis paniculata plant extracts in streptozotocin induced diabetic rats. Intern J of Pharm and Pharmac Sci. 2013;55(3):305-11.

\section{GRAPHICAL ABSTRACT}

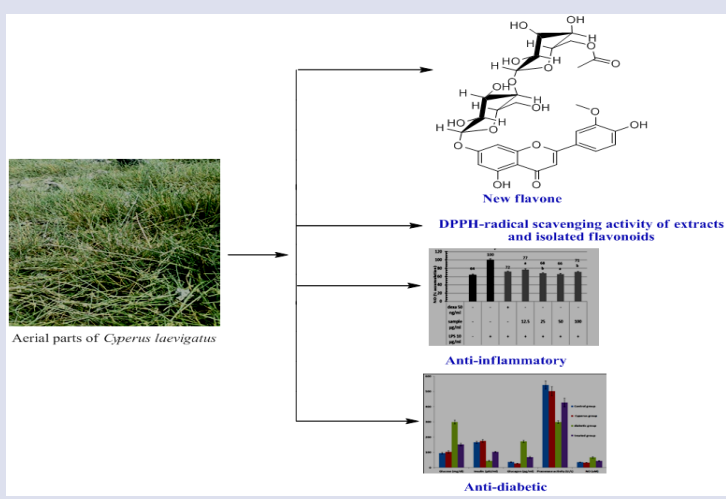

\section{SUMMARY}

- Isolation and identification of a new flavonoid along with 7 knowns fron aerial parts of C. laevigatus.

- Evaluation of antioxidant of the isolated flavonoids.

- Evaluation of anti-inflammatory of the different solvent successive fractions.

- Study of andtidiabetic activity of the total alcoholic extract.

\section{ABOUT AUTHORS}

Yomna M. Yassine is a doctoral researcher at National Research Centre, Egypt. She finished her Msc in 2016 from Faculty of Pharmacy; Ain Shams University; Egypt. Her research topic is isolation and identification of bioactive constituents from natural resources

Prof. Dr. Abdel-Razik H. Farrag is a professor of Pathology, Pathology Department, National Research Centre, Egypt. His research topic is study of histological and histochemical effects of natural products from plants and marine soft corals.

Prof. Dr. Mahmoud I. Nassar; is a professor of Natural Product Chemistry, Natural Compounds Chemistry Department, National Research Centre, Egypt. His research topic is isolation and structure elucidation of bioactive constituents from medicinal plants and marine soft coral such as flavonoids, steroids, ceramides and volatile oil.

Cite this article: Elshamy Al, El-Shazly M, Yassine YM, El-Bana MA, Farrag AH, Nassar MI, Singab ANB, Noji M, Umeyama A. Phenolic Constituents, Anti-Inflammatory and Antidiabetic Activities of Cyperus laevigatus L.. Pharmacog J. 2017;9(6):828-33. 